29 Reitan R. Validity of the Trail Making Test as an indicator of organic brain damage. Percept Mot Skills 1965; 8: 271-6.

30 Isaac B, Kennie AT. The Set test as an aid to the detection of dementia in old people. Br J Psychiatry 1973; 123: 467-70.

31 Dubois B, Touchon J, Portet F, Ousset PJ, Vellas B, Michel B. 'The 5 words': a simple and sensitive test for the diagnosis of Alzheimer's disease [in French]. Presse Med 2002; 31: 1696-9.

32 Artero S, Ancelin ML, Portet F, Dupuy A, Berr C, Dartigues JF, et al. Risk profiles for mild cognitive impairment and progression to dementia are gender specific. J Neurol Neurosurg Psychiatry 2008; 79: 979-84.

33 Lawton MP. Scales to measure competence in everyday activities. Psychopharmacol Bull 1988; 24: 609-14.

34 Katz S, Ford AB, Moskowitz RW, Jackson BA, Jaffe MW. Studies of illness in the aged. The index of ADL: a standardized measure of biological and psychosocial function. JAMA 1963; 185: 914-9.

35 Harwood RH, Prince MJ, Mann AH, Ebrahim S. The prevalence of diagnoses, impairments, disabilities and handicaps in a population of elderly people living in a defined geographical area: the Gospel Oak project. Age Ageing 1998; 27: 707-14.
36 Wilhelm K, Mitchell PB, Niven H, Finch A, Wedgwood L, Scimone A, et al. Life events, first depression onset and the serotonin transporter gene. Br J Psychiatry 2006; 188: 210-5.

37 Hariri AR, Drabant EM, Munoz KE, Kolachana BS, Mattay VS, Egan MF, et al. A susceptibility gene for affective disorders and the response of the human amygdala. Arch Gen Psychiatry 2005; 62: 146-52.

38 Heinz A, Braus DF, Smolka MN, Wrase J, Puls I, Hermann D, et al. Amygdala-prefrontal coupling depends on a genetic variation of the serotonin transporter. Nat Neurosci 2005; 8: 20-1.

39 Taylor SE, Way BM, Welch WT, Hilmert CJ, Lehman BJ, Eisenberger NI. Early family environment, current adversity, the serotonin transporter promoter polymorphism, and depressive symptomatology. Biol Psychiatry 2006; 60: 671-6

40 Surtees PG, Wainwright NW, Willis-Owen SA, Luben R, Day NE, Flint J. Social adversity, the serotonin transporter (5-HTTLPR) polymorphism and major depressive disorder. Biol Psychiatry 2006; 59: 224-9.

41 Cooper RS. Gene-environment interactions and the etiology of common complex disease. Ann Intern Med 2003; 139: 437-40.

42 Kruijshaar ME, Barendregt J, Vos T, de Graaf R, Spijker J, Andrews G. Lifetime prevalence estimates of major depression: an indirect estimation method and a quantification of recall bias. Eur J Epidemiol 2005; 20: 103-11.

\section{0 words}

\title{
Melancholia
}

\section{Alistair Stewart}

'I got stones in my pathway/And my road seems dark at night/I have pains in my heart/They have taken my appetite'. Robert Johnson, known as the King of the Delta blues singers, distilled into these lines the essence of severe depressive illness - somatic ills, fear and suspicion, emotional and physical pain, nocturnal troubles and struggle against obstacles. The words are one with the powerful, haunting music. ICD-10 and DSM-IV have their place, but poets have often been there before us, and done a better job. We can all learn from Robert Johnson, born just 100 years ago. 